A.A. Sheptalin, Candidate of Sciences (History), Docent of the Theory and History of State and Law Department, Udmurt State University

\section{THE GENESIS}

OF THE INSTITUTION

OF SUBJECTION

IN THE SYSTEM

OF SOCIAL POWER

AND SOCIAL

NORMATIVE

REGULATION

An attempt to reconstruct the genesis of the institution of subjection in the system of social power and social normative regulation during the pre-state period is made. The author considers the scope of violent and nonviolent power implementation methods in complex as a subjection institution that consists of such influence methods as persuasion, motivation, compulsion and coercion. The main phases of the subjection institution genesis are substantiated based on three development stages of the primitive community.

Key words and word-combinations: power, subjection, management sociology, social normative regulation.
A.A. Шепталин, кандидат историеских наук, дочент кафедрь теории и истории государства и праља Удмуртского государственного yнubepcumema (email: sheptalin@list.ru)

\section{ГЕНЕЗИС \\ ИНСТИТУТА ПОАЧИНЕНИЯ \\ B СИСТЕМЕ \\ СОЦИААЬНОЙ ВААСТИ \\ И СОЦИОНОРМАТИВНОГО РЕГУ ИИРОВАНИЯ}

Аннотация. Предпринята попытка реконструкции генезиса института подчинения в системе социальной власти и соционормативного регулирования в догосударственный период. Рассматривается совокупность насильственных и ненасильственных способов реализации власти в качестве института подчинения, состоящего из таких способов воздействия, как убеждение, побуждение, понуждение и принуждение. Систематизированы основные стадии генезиса института подчинения на трех этапах развития первобытной общины.

Ключевые слова и словосочетания: власть, подчинение, социология управления, соционормативное регулирование.

K омиизии взаимоотношений общества и института власти в их исторической ретроспективе традиционно находятся в центре исследовательского внимания, от- 
мичаются высокой степенью актуальности и обширной мультидисщиплинарной историографией. Отход от марксистско-менинской методологии в постсоветский период существенно катализировал дискуссии в науке теории и истории права и государства, что способствовацо актуацизации вопросов правопонимания, первичности и соотношения права и государства. В Аанной публикации попытаемся подвергнуть критическому анализу этатистскопозитивистский тезис, с 1938 г. насаждавшийся в советском правоведении, о том, что право санкционировано государством и гарантируется его принуАительной силой [1, с. 83]. Сегодня, хотя и не в столь категоричной форме, бытует мнение, что «охрана государственным принуждением - спеџифический признак правовых норм...» [2, с. 59]. Сторонники подобных взглядов отводят государству решающую роль в возникновении права, так как оно формирует аппарат принуждения, без которого право не может быть эффективным регулятором общественных отношений и выполнять стоящие переА ним задачи [3, с. 30].

Представляется, что предвзятость позитивистов, традиџионно отождествляющих понятия «право» и «законодательство», «принуждение» и «госуАарственное / правовое принуждение», носит субъективный характер. СлеАует обратить внимание на данные юридической антропологии, которые свидетельствуют о наличии достаточно эффективного механизма подчинения, обеспечивающего следование нормативным требованиям еще в догосударственных социальных системах. Цель Аанной статьи состоит в попытке реконструкции генезиса и формирования института подчинения в системе социальной власти и соџионормативного регулирования в догосударственный период. В качестве важнейших задач исследования можно определить обоснование института подчинения как основы соџиального регулирования и управления в первобытном обществе; выделение на этнографическом материале основных способов подчинения объекта волевых отношений в первобытном обществе; выявление специфики эволюџии способов подчинения на ранних этапах развития общины.

Институт подчинения в доклассовом обществе составляет междисциплинарный предмет изучения, находящийся на стыке интересов юриспруденџии, юридической и политической антропологии, истории первобытного общества, политологии, соџиологии и философии. Историография вопроса сколь обширна, столь и противоречива вслеАствие разного понимания авторами таких ключевых категорий, как право, власть, принуждение, соџиальная норма, нормативное регулирование, обычай, правовой обычай, обычное право и т.п.

По общему мнению большинства авторов, институт власти занимает центральное место в системе соџиального рекрутирования и регулирования. Несмотря на обилие подходов и мнений, кмассическим считается определение власти, данное еще в 1922 г. выдающимся немецким соџиологом, автором конџепџии власти, трактуемой как способность / возможность воздействия на поведение мюдей, М. Вебером: «ВАасть означает мюбую способность (Chance) реализаџии своей воли внутри данного соџиального отношения 
Ааже вопреки противодействию, на чем бы эта возможность ни основыва-

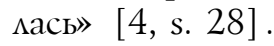

По данному определению, суть власти заключается в навязывании субъектом своей воли объекту, то есть подчинении объекта соџиального воздействия, Ааже несмотря на противодействие последнего. В спещиальной митературе Аля обозначения проџесса навязывания воли субъекта объекту широкое распространение получия термин «принуждение», имеющий различные опредемения в зависимости от контекста. ОАнако в качестве элемента системы социальной власти и соџионормативного регулирования принуждение чаще всего рассматривается как способ социального воздействия [5, с. 26], метоА осуществления власти [6, с. 63], виА власти [7, с. 282], разновидность соџиального управления $[8$, с. $5-12]$.

Аискуссия об институте принуждения и его перспективах в советском праве развернулась в 1960-е годы в контексте ожидавшегося в Советском Союзе построения социализма и коммунизма [9]. Несмотря на Аавность практики использования терминов «принуждение» и «институт принужАения» применительно к проџессу реализаџии соџиальной власти и соџионормативному регулированию, необходимо признать, что они включают в себя мишь часть среАств и методов воздействия. Наряду с принуждением у разных авторов фигурирует ряд иных категорий, наиболее частые: «убеждение», «побуждение», «понуждение» [5, с. 26] , «авторитет», «манипумяџия», «сила» и Аругие [7, с. 282].

Не вызывает особого обсуждения утверждение о том, что принуждение связано в первую очереАь с угрозой физического мибо психологического, вкмючая идеологическое, воздействия [10, с. 78]. По Аанной причине у большинства современных авторов принуждение напрямую ассоциируется с государством, обладающим соответствующим аппаратом насилия, а в предметно-объектной обкасти их иссмедований фигурирует государственное [11] и государственно-правовое принуждение в тех ици иных аспектах [12]. Вместе с тем, учитывая опыт использования иных методов, не связанных с угрозой применения насилия, следует признать, что собирательный термин «институт подчинения» Аучше подходит Амя обозначения всей совокупности способов, методов и форм реализации власти в социальных отношениях и управлении, включая такие, как убеждение, побуждение, понуждения, принуждение.

При всей многовариантности проџессов возникновения в разАичных частях ойкумены института публичной власти следует признать, что на раннем этапе эти проџессы протекали в рамках относительно универсальной модели. Возникновение института власти и соџиального управления тесно связано прежде всего с первой формой функционирования собственно чемовеческого общества - родовой (кровнородственной) общиной и такой ее разновидностью, как раннеродовая община. Поскольку не все чмены родовой общины принадлежали к оАному роду, пробцемы профикактики конфликтов приобрели в ней актуальность еще на самой ранней стадии социогенеза. 
Острая дискуссия о корректности «эволющионного» метода А.Г. Моргана, активно использовавшего этнографический материал при реконструкции соџиальных форм первобытности, имеет давнюю историю, но сегодня уже не так остра [13]. В свете научной конџепции мультицинейного неоэволюџионизма очевиАно, что в условиях отсутствия прямых источников именно этнографические сведения должны быть положены в основу комплексного метода с использованием всех косвенных данных, предмагаемых гуманитарными и естественноисторическими науками. В Аанном случае в качестве источников использованы этнографические материалы XIX - начала XX в. по синполитейным первобытным племенам, сохранившим многовековой образ жизни и не успевшим подвергнуться серьезному вциянию цивилизации.

В обширной этнографической и антропологической митературе содержится масса фактов по юридическому быту разных этносов, в том числе по вопросам преступления и наказания, принуждения и насилия и т.А. ОАнако в целом институт подчинения и его составляющие еще не становились предметом специального рассмотрения. Аанное исследование явмяется, по сути, первой в юридической антропологии пробной попыткой поэтапной реконструкции генезиса института подчинения в первобытном обществе на этнографическом материале по синполитейным первобытным обществам.

Использование комплексного подхода дает основания дмя утверждения тезиса о возможности выдемения из животного мира человеческого общества раннеродовой общины - благодаря появлению соџиального регулирования в форме экзогамии и простейших запретов. Возникли и развивались представления об основных правах и обязанностях, совокупность которых расширялась и усложнялась по мере социализации человека.

Вопреки распространенному заблуждению о неразвитости нормативного регулирования в первобытности наличие механизма подчинения бымо свойственно человеческому обществу, очевидно, уже на самых ранних этапах. Стадиально наиболее архаичным этносом, описанным европейскими путешественниками, были аборигены о. Тасмания. По сообщениям очевидцев, в военный период каждое племя имело вождя, обладавшего большой властью, вплоть Ао возможности Аишения жизни Аюбого чмена племени $[14$, c. 32$]$.

Миссионер М. Гусинде отмечал, что у племени селькнамов (уна) отсутствовали меры внешнего принуждения. Существующий порядок и общеобязательность определенных действий целиком выводится из религиозно-мифомогических преАставлений, а «бцагоговение переА традицией», по его словам, обеспечивает самое сильное принуждение [15, s. 461]. Каждый общинник постоянно был в курсе правильности своего поведения, поскольку окружающие насмешками, увещаниями ими окриками безжалостно указывали на мюбые его ошибки.

Основы нормативного поведения закмадывались еще в период прохождения молодежью обряда инициации, который мог продолжаться много 
месяџев. Из рассказов стариков, посредством убеждения молодые мюди усваивали информаџию о том, как божественные первопредки и герои прошиого поступали в разцичных сложных ситуациях, создав образцы поведения.

ОАной из составмяющих убеждения бымо предостережение от совершения асоциальных деяний, обусловленных многочисленными табу. Вероятно, тогда же начиналось и воздействие такого способа, как побуждение, поскольку возникала необходимость направить молодежь в русло действий, полезных общине. Известный исследователь аборигенов Австралии Ф. Роуз отмечал, что более половины мясной пищи на охоте добывали юноши в возрасте до шестнадцати мет, не прошедшие обрядов инициаџии, а также молодые неженатые мужчины [16, с. 134]. Очевидно, они были мотивированы на повышение своего статуса и авторитета дмя получения взамен определенных привилегий.

Во многих архаичных родовых обществах способы воздействия были достаточно корректными. Так, известный исследователь индейских племен Великих равнин Э.А. Хёбель писал, что у охотников команчей «вождь был магнитом в центре группы, но его влияние было настолько тонким, что оно почти не подАается явному описанию. Он действовац через наставления, советы и добродушный юмор, выражая свою мудрость через тщательно подобранные слова и убедительный зАравый смысл» [17, р. 132].

Первый деликт прощался мегче, но рецидив, как и серьезное первичное нарушение, неминуемо влекли наказание. Например, у селькнамов вместо насилия община просто разрушала репутацию девианта, избегая контактов с ним, таким же образом поступали и андаманџы [14, с. 89]. У австралийских аборигенов встречались более жесткие санкции, вследствие чего девианты Ааже перебегали в соседние племена, чтобы получить убежище и избежать наказания $[14$, с. 74$]$.

У селькнамов обиды и нарушения не прощались, Аишь родичи могли рассчитывать на снисхождение. Оскорбления часто заканчивались убийством. Пострадавший мог пубцично оскорбцять и показывать пальцем на обманщика и вора. Родственники жены жестко, не церемонясь, ставили на место грубого мужа. Обманутый супруг получал право на публичное оскорбление и рукоприкладство. Позором считалось не только быть уличенным в неблаговидном поступке, но даже быть заподозренным [15, s. 462].

Таким образом, уже с периода ранней первобытности каждый индивиА с детства посредством убежжения приобщался к нормативным ценностям и испытывал побуждение со стороны общины, управцявшейся на принщипах народовластия и комлективной воли, к «правимьному» поведению в соответствии с обычаями предков. Только так он мог год от года укреплять свой авторитет, что в конечном итоге гарантировало его определенный соџиальный успех, по крайней мере, создавало для него прочный фундамент.

На этапе развитого первобытного общества (позднеродовой общины), характеризующегося переходом к высокоспециализированному присваивающему или раннему производящему хозяйству, существенно возросла степень 
регламентированности поведения и контромя со стороны вождей и старейшин. Б.К. Малиновский отметил даже своего рода «гипертрофию закона» [18, с. 216]. В связи с усложнением верований возникла масса новых табу. КажАый индивид бым мотивирован на соответствие обычаям предков, поскольку изгнание, например у папуасов о. Новая Гвинея, неминуемо вело к гибели, в том числе и от соседей-каннибалов [19, с. 58].

Разросшаяся община стала многородовой, а потому более сложно управмяемой. К способам подчинения в этот периоА Аобавицись принуждение и насилие. Принуждение было институтом эффективным, но конфмиктогенным, а потому использовалось мишь в крайних случаях, как и прямое насилие. Известно, что эскимосы применяли принуждение в отношении рецидивистов, как и некоторые племена папуасов, практиковавшие межкобщинный обмен злостными нарушителями, которых в качестве первой жертвы казнили подростки [19, с. 63]. У индейцев омаха совет племени после предупреждения мог принять решение об убийстве неисправимого девианта [20, p. 416].

При изучении этнографического материала невольно возникает мысль, что поведенческие нормы и обычаи целенаправленно усложнялись, чтобы чиен общины всегда находияся на грани фола - так им было мегче управцять. Например, у арапешей Новой Гвинеи девиантные проявления были настолько реАкими, что общественное пориџание стало распространяться Ааже на случаи, когда об антиобщественном поведении вообще не могло быть речи, например за ранение, полученное на охоте. В таком и подобных случаях пострадавший порицался за беспечность, жертва оскорбления - за глупость, жертва насилия - за непредусмотрительность, пострадавший в столкновении - за пролитую семейную кровь (пусть Аажке и его собственную!) $[19$, c. 249] .

В рассматриваемый период позАнеродовой общины изменилась роль экономического понужАения в системе поАчинения, поскольку к нарушителям все чаще стали применяться имущественные санкщии. Ааже незначительное асоциальное деяние обретало материальный эквивалент. Общинникам пришлось стать предусмотрительнее в своем поведении, чтобы не оказаться в положении, выход из которого мог обойтись Аостаточно Аорого [19, с. 269].

В усложнившейся позАнеродовой общине получия распространение институт кровной мести, регулировавший отношения межАу родами и субкланами. Убийство человека восприниманось как оскорбление всего рода, а объектом мести мог стать не только убийца, но и его родственник, что вело к затяжным конфликтам. Угроза кровной мести была сдерживающим фактором и важным элементом системы принужАения в позАнеродовой общине.

На этапе позАнепервобытного общества (гетерогенной общины) произошми существенные социально-экономические и кумьтурные изменения, привеАшие к распаду родового строя. Институционализация семейной собственности, имущественная и социальная дифференциация, усложнение межплеменных 
связей, отделение ремесла и ряд Аругих факторов усложнияи общую картину соџионормативного регулирования.

Ослабление родовых связей, включая такой способ воздействия, как убеждение, способствовало перераспределению ролей в пользу Аругих способов, в частности, побуждения. Развитие производящего хозяйства, материального производства и товарообмена вели к усилению частнособственнических интересов, формированию в обществе комплекса взаимных обязательств. По мнению Б.К. Малиновского, эти обязательства выливацись в цепь сделок и взаимных услуг, каждая из которых должна была через определенное время вознаграждаться. Особую роль стали играть публичность и џеремониальность саелок и договоренностей, что укрепляло порядок, сику «закона», в обществе меланезийџев [18, с. 228-229]. Тот же принцип можно видеть в религиозных обрядах, в которых большинство актов выступают в качестве взаимного обязательства между группами и индивидами, с обязательной платой или ответной услугой, что закреплено обычаем. Меланезийџы, по сути, понимали мюбой религиозный акт как моральную обязанности по отношению к духам, призракам ици предметам покмонения [18, с. 233-234].

Сила взаимных обязательств была столь велика, что даже племенные вожди, наделенные большой властью и полномочиями, были заложниками многочисленных формальностей. Так, у меланезийцев вождь, возжелавший «объявить войну, организовать экспедиџию или устроить праздничное торжество, АОАжен выступить с формальным воззванием, публично огласить свою волю, посоветоваться со старейшинами, принять в соответствии с ритуалом поАношения, ускуги и помощь своих подданных и, наконец, вознаградить их за все это по определенной таксе» $[18$, с. 235]. Система подчинения работала настолько эффективно, что девиант выглядец «смешным, неловким и неотесанным» не только в чужих, но и в собственных глазах [18, с. 238]. У африканских племен, где статус вора был не столь позорным, как у индейџев Америки или меланезийџев, общество вводимо дополнительные запретительные мотивы - в дополнение к всеобщему пориџанию вор должен был вернуть пострадавшему Авойной размер украденного [21, с. 246] .

В позднепервобытном обществе на новый уровень развития вышел институт принуждения как крайний и наиболее эффективный способ вАияния. Например, нарушение экзогамии вмекло такое психологическое воздействие со стороны общества, что это часто заканчивалось самоубийством [18, с. 251] . ОАним из вариантов психологического воздействия была магическая практика, когда комдун, заручившись общественной поддержкой, за вознаграждение вставац на сторону пострадавшего и насылац на виновного змые чары и порчу. По замечанию Б.К. Малиновского, «в таких случаях жертва, узнав, что чародей действует против нее, может также отступить, возместить ушерб или полюбовно завершить дело. Таким образом, черная магия обычно действует как реальная сила закона, ибо используется дмя выполнения правил племенного закона, препятствует насилию и восстанавливает равновесие» $[18$, c. $255-256]$. 
По мере ослабления родовых связей подчинять волю общинников прежними средствами было все сложнее. Нередко эти средства становились более жесткими. Так, у многих племен обряд инициации юношей обрел довольно кровавые формы, чтобы боль и страх сохранились в сознании на всю жизнь, напоминая о возможных последствиях своеволия. Психологическое и физическое принуждение, таким образом, распространияось на все возрастные категории. В этом контексте примечатемен пример, приведенный М. МиА, как индейџы племени зуньи, избегая открытых ссор со своими детьми, проявцяя внешнюю снисходительность и миролюбие, втайне приглашали танџоров в страшных масках прийти к ним в дом и побить оскушников $[19$, c. 333].

В гетерогенной общине стали широко практиковаться угроза и применение физического воздействия [20]. Аишение жизни могмо последовать за преступление против общества или вождя: за мюбое нарушение этикета, церемониала, прелюбодеяние с какой-то из его жен, кражу его мичной собственности или мюбую кичную обиАу [18, с. 259]. У ифугао Филиппин возмездие посреАством убийства было обычным способом удовцетворения постраАавшей стороны в случае убийства, колдовства, прелюбодеяния, отказа платить компенсацию за причиненный ущерб и упорный, сознательный отказ от уплаты АОлга, когда есть возможность заплатить [17, с. 249] .

Вопреки встречающемуся в митературе мнению об отсутствии аппарата принуждения в первобытном обществе следует отметить, что во многих потестарных обществах на стадии распада родовой общины такой аппарат существовац [21]. Например, у ирокезов осужденные советом племени на смертную казнь или физическое наказание передавались палачам, которые

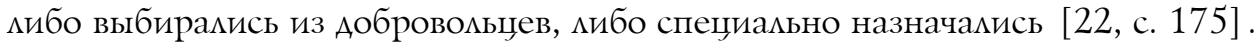
Подобные примеры можно привести по Африке, Океании, Сибири и т.А. Конечно, так было не везде. Например, вследствие спещифики трайбализма подобного рода структуры не сложились у ряда этносов Экваториальной Африки, что показал один из основоположников юридической антропологии Э.Э. Эванс-Притчард на примере нуэров, вожди которых так и не смогли усилить свою власть, оставшись Аишь посредниками в межккановых конфАиктах [23, с. 154-155] .

Важную роль в системе принуждения играла угроза изгнания [18, с. 265-266]. По свидетельству М. МиА, глубоко изучившей жизнь аборигенов, на о. Бали пару, уличенную в инџесте, изгоняли в страну наказания, «где царят только боги смерти» [19, с. 308]. Безусловно, изгнание является уже не угрозой, а жесткой санкцией и формой насилия, но яркие прецеденты негативных санкций в отношении девиантов играли важную роль в повышении эффективности принуждения.

Институт кровной мести в рассматриваемый период достиг своего апогея, получив широкое распространение. Вместе с тем соџиально-экономические тенденџии эпохи стимулировали появление примирительной практики выплаты компенсации. У чценов рода не было интереса втягиваться в кровопролитный конфликт, и они оказывали влияние на семью убитого, чтобы

\section{Bulletin of the Volga Region Institute of Administration • 2018. Vol. 18. № 6}


те приняли «плату за кровь», что освобождало род от обязанности мщения. Известны случаи, например, у оленных чукчей, когда родственники превентивно убивали задиристого чцена кмана, опасаясь, что придется вести «вражАу кровомшения», если это сделает чужак [24, с. 180]. По словам Б.К. Малиновского, кажущаяся монолитность рода сочеталась с Аалеко идущей дифференциацией, со строгим соблюдением индивидуальных интересов и «... типично коммерческим духом, не свободным от подозрительности, зависти и обмана» $[18$, c. $271-272]$.

БАагодаря наличию репрезентативного этнографического материала преАставцяется возможным сделать вывод, что система подчинения в позАнепервобытном обществе Аостигла такого уровня, который позволиц авторитетному специалисту в области юридической антропологии Н. Рулану утверждать, что «...уголовная система существует уже в традиџионных обществах и что наказание не обязательно связано с наличием государственного аппарата» [25, c. 181].

Как видим, институт вцасти и управления в первобытном обществе формировался на основе не столько принуждения, сколько системы подчинения, вкцючавшей в себя как насицьственные, так и ненасильственные способы навязывания воли субъекта объекту: убеждение, побуждение, понуждение, принуждение. Все они возникми на самом раннем этапе развития человеческого общества, развивались парамлельно, на разных этапах играя то большую, то меньшую роль, в зависимости от соџиально-экономических изменений. В связи с этим необходимо отметить Аискуссионность феномена насиция (силы), которое рядом исследователей рассматривается как еще один самостоятельный способ подчинения и осуществления вмасти [7, с. 282-285].

Аействительно, прямое применение насилия выходит за рамки принуж-

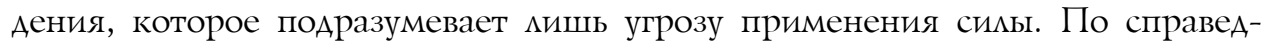
мивым оценкам некоторых авторов, отождествление применения насиция и угрозы насилия фактически принижает роль принуждения [26, р. 26-27]. Ввиду различия авторских подходов и определений подобная точка зрения

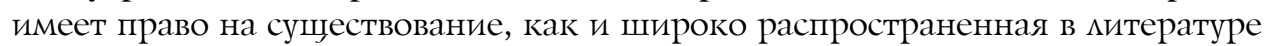
практика отождествления насиция с институтом принуждения (соџиального или государственного) $[27$, с. 21].

Таким образом, генезис системы института подчинения в условиях потестарной организации общества обусловливает по мере трансформации субъекта волевых отношений в ходе трех рассмотренных этапов постепенную концентрацию власти в руках авторитетных индивидов (шаманов, вождей, старейшин и Ар.). Вслед за исследователем потестарного общества $\Lambda$.Е. Куббелем правомерно было бы сформулировать определение потестарной власти в качестве власти комлектива, реализуемой «... через авторитет индивида, выполняющего функции мидера в Аанной конкретной ситуации» $[10$, c. 116$]$.

У многих этносов потестарная власть достаточно эффективно регулировала общественные отношения, поддержкивала порядок и стабильность, предуп- 
режАала и разрешала конфликты, содействовала достижению общественного согласия задолго до появления институтов государства и позитивного права. Результаты анациза генезиса института подчинения демонстрируют высокий потенциал ненасильственных методов воздействия, которые при определенных условиях пригодны к более эффективному применению в системе соџиальной вцасти и соџионормативного регулирования на современном этапе.

\section{Библиографический список}

1. Вышинский А.Я. Вопросы теории государства и права. М., 1949.

2. Лейст О.Э. Сущность права. Проблемы теории и философии права. М., 2002.

3. Егоров В.С. Общее понятие правового принуждения // Вестник Пермского университета. Юридические науки. 2007. № 8 (13). С. 29-35.

4. Weber M. Wirtschaft und Gesellschaft: GrundriЯ der verstehenden Soziologie. Besorgt von Johannes Winckelmann. - 5., rev. Aufl., Studienausg., Tьbingen: Mohr, 1980.

5. Черных Е.Н., Венгеров А.Б. Структура нормативной системы в древних обществах (методологический аспект) // От доклассовых обществ к раннеклассовым. М., 1987. С. 23-37.

6. Кейзеров Н.М. Власть и авторитет: критика буржуазных теорий. М., 1973.

7. Ледяев В.Г. Власть: концептуальный анализ. М., 2001.

8. Колотуша В.В. Смысловые границы понятия силового принуждения // Вестник РУДН. Сер.: Философия. 2008. № 4.

9. Ардашкин В.Д. О подчинении и принуждении в советском государственном управлении // Вопросы советского государства и права. Томск, 1966. Т. 183. С. 246-252.

10. Куббель Л.Е. Очерки потестарно-политической этнографии. М., 1988.

11. Каплунов А.И. Об основных чертах и понятиях государственного принуждения // Государство и право. 2004. № 12. С. 10-17.

12. Чашников B.A. Государственно-правовое принуждение: общетеорети-ческие вопросы: дис. ... канд. юрид. наук. Екатеринбург, 2006.

13. Шепталин А.А. О применимости этнологических материалов при реконструкции генезиса права и государства // Вестник Удмуртского университета. Сер. 2: Экономика и право. 2016. Вып. 2. С. 137-143.

14. Кабо В.Р. Первобытная доземледельческая община. М., 1986.

15. Gusinde M. Die Feuerland-Indianer // Die Selk’nam. Mцdling bei. Wien, 1931.

16. Роуз Ф. Аборигены Австралии. Традиционное общество / пер. с англ. М., 1989.

17. Hoebel E.A. The Law of Primitive Man: A Study in Comparative Legal Dinamics. Cambridge: Harvard University Press, 1954.

18. Малиновский Б. Избранное: Динамика культуры / пер. с англ. М., 2004.

19. Мид М. Культура и мир детства // Избранные произведения / пер. с англ. М., 1988.

20. Lowie R.H. Primitive Society. New York, 1920.

21. Рэдклиф-Браун А.Р. Структура и функция в примитивном обществе / пер. с англ. M., 2001.

22. Морган Л.Г. Лига ходеносауни, или ирокезов / пер. с англ. М., 1983.

23. Эванс-Причард Э.Э. Нуэры. Описание способов жизнеобеспечения и политических институтов одного из нилотских народов / пер. с англ. М., 1985.

24. Богораз В.Г. Чукчи: в 2 ч. / авториз. пер. с англ. Л., 1934. Ч. 1.

25. Рулан Н. Юридическая антропология. М., 1999.

26. Wrong D.H. Power: Its Forms, Bases and Uses. Oxford: Basil Blackwell, 1988.

27. Киреев Г.Н. Сущность насилия. М., 1990. 